\title{
Determination of Energy and Nutrient Intakes in Pediatric Burned Patients
}

\author{
Sule Aktac ${ }^{1}$, Izel Aycan Basoglu² ${ }^{2}$, Aybike Cebeci ${ }^{\circledR}$, Esma Oguz ${ }^{2}$, Begumhan Omeroglu Gulada ${ }^{\mathbb{D}}$ \\ ${ }^{1}$ Marmara University, Faculty of Health Sciences, Department of Nutrition and Dietetics, Istanbul, Turkey. \\ ${ }^{2}$ Marmara University, Institute of Health Sciences, Department of Nutrition and Dietetics, Istanbul, Turkey. \\ Correspondence Author: Sule Aktac \\ E-mail: sule.aktac@marmara.edu.tr \\ Received: $11.06 .2020 \quad$ Accepted: 16.09 .2021
}

\begin{abstract}
Objective: The prevalence of malnutrition defined by nutritional insufficiency is substantially high in children admitted to the burn center. This study aimed to evaluate the energy and nutrient intakes of pediatric burned patients.

Methods: This prospective study was conducted between May 2016 and January 2017, involving 45 (2 to 18 years old) children and their caregivers. Data were collected via three $24 \mathrm{~h}$ dietary recall, socio-demographic questionnaire, and assessment of clinical characteristics was done in the Hospital Burns Centre. The energy and nutrient intakes of pediatric burned patients were calculated using computer software and compared with the nutritional recommendations. Statistical tests included analyses of t-test, ANOVA, Pearson Correlation test, and $x 2$ tests.

Results: None of the children reached the requirements for energy and macronutrients. There was a negative correlation between the meeting of requirements and the age $(P<0.05)$. Oral enteral nutrition increased the meeting energy requirements $(P<0.05)$. Depending on the presence of a perioperative fasting period, the percentage of children who met the energy and protein requirements was significantly lower $(P<0.05)$. The burned area did not affect the percentage of children meeting their energy and protein intakes $(P>0.05)$.

Conclusions: Oral enteral nutrition facilitates the ability of children to reach requirements; however, perioperative fasting periods and age are barriers to ensure adequate energy and nutrient intake in pediatric burned patients. Therefore, individualized nutritional support and education is vital for burned children to meet increased energy and nutrient requirements.
\end{abstract}

Keywords: Nutritional status, child, burns, energy intake, nutrient intake.

\section{INTRODUCTION}

Burns are acute and preventable injuries caused by exposure to heat, electricity, chemical substances, and radioactive or caustic agents that affect the skin and/or subcutaneous tissues (1). Burns affect an average of 2.5 million people every year worldwide (2). Because burns result in a loss of skin, burned persons may develop fluid-electrolyte disorders and severe catabolism, leading to energy, protein, and micronutrient deficiencies. Burns that negatively affect the entire organ system are one of the most important causes of morbidity and mortality, particularly in children. Burns are among the second - or third-ranked causes of mortality in children depending on the age, burn area, and degree. In addition, burn-related mortality rates increase up to 4 years old (3-6). Inhalation burns and sepsis are also common causes of mortality from burns (3).

Risk factors that cause burns vary depending on the country, region, education level, culture, socioeconomic status, habits, living conditions, and environmental conditions (7). The most common burns in children are caused by scalding, flames, and electrical and chemical burns; the upper and lower extremities are the most commonly burned areas, and second-degree burns are the most frequent type (8). In a study conducted in Turkey, scalding was the most common type of pediatric burns and the most common cause of scald injuries were hot water or hot tea and coffee. In the same study, the upper and lower limbs were involved in 41.2 and $43.0 \%$ of the patients (9).

Pediatric burns require a multidisciplinary approach and are difficult to treat (1). Nutritional support is also considered an important component of burn treatment. In moderate to severe burns, providing adequate nutritional support is important for reducing mortality and morbidity. The negative clinical outcomes lead to a hypermetabolic condition in which burned children are at risk of malnutrition (6). In a study conducted in the USA, malnutrition was detected in $23.8 \%$ patients in the pediatric burn unit and the highest rate was found in the youngest age (0-3 years) (95\%) (10).

It is important to ensure adequate nutrition and weight tracking to prevent weight loss because late wound healing, muscle 
atrophy, growth retardation, decreased immuno-competence, and protein and energy malnutrition become apparent with weight loss during the treatment process (6). Burn traumas have more effects than adults due to the fact that children are in the age of growth and their physical activities are high (11). Pediatric burned patients must remain in the normal growth range according to their age and gender (12).

Given the importance of nutritional support, the purpose of this study was to evaluate the energy and nutrient intake of pediatric burned patients and compare with requirements.

\section{MATERIALS AND METHODS}

\subsection{Subjects and Study Design}

This prospective study was conducted in the Dr. Lutfi Kirdar Education and Research Hospital Burn Centre in Istanbul/ Turkey, between May 2016 and January 2017. The study comprised 51 pediatric burned inpatients ( 25 females and 26 males) aged 2-18 years who were admitted to the burn centre. Enterally and orally fed children were included in this study. Five children and caregivers who didn't accept to participate in the study and one parenterally fed child were excluded. There was no specific routine nutrition support program that the hospital applies to the pediatric burned patients in the burn centre. High energy $(1 \mathrm{ml}=1.5 \mathrm{kcal})$ and $8 \%$ protein products were used as oral enteral products in the burn centre.

A total of 45 children were included in this study. Permission to conduct the study was granted by the Ethics Committee of the Marmara University School of Medicine (Approval date: 01.04.2016 - No: 09.2016.255). All children and caregivers who volunteered to participate in the study provided written informed consent. All questionnaires were administered by researchers in face-to-face interviews with the children and caregivers. Before the interview, the participants received an oral explanation of the study purpose.

\subsection{Data Analysis and Dietary Assessment}

Data were collected via a socio-demographic questionnaire (age, height, weight, etc.), an assessment of clinical characteristics (Total body surface area (\%TBSA) of burn, burn degree, burn area, and burn cause), and three $24 \mathrm{~h}$ dietary recalls (24-HDRs) administered by dietitians. The weight percentile for age was calculated from standard pediatric growth charts (13). The questionnaire consisted of 4 sections and 20 questions about the children, family, hospital food, and food records. Classification of burn severity was evaluated on the basis of Murray (2007) (14). Daily energy and nutrient intake was calculated by using computer software (Ebispro, Stuttgart, Germany; Turkish version: BeBiS, Vers. 6.1). The daily average energy requirement was determined with the Curreri formula, macronutrient and micronutrient requirements were evaluated on the basis of Chan et al. (6), Clark et al. (15) and Rodriguez et al. (16) (Table 1).
The daily average energy and nutrient intake were also evaluated according to the perioperative fasting period (applying before routine practices such as washout, dressing changes, and surgery for burns). The American Society of Anesthesiologists (ASA) practice guideline was used to determine the perioperative fasting period (17). The ASA practice guideline (2011) valid at the time of the study was suggested the following to reduce the severity of complications related to perioperative pulmonary aspiration of gastric contents; restriction of clear fluids for two hours, breast milk for four hours, infant formula for six hours, a light meal or non-human milk for six hours or more, and a meal that include fried or fatty foods or meat for eight hours (17).

Table 1. Energy and nutrient requirements

\begin{tabular}{|c|c|}
\hline Energy and nutrients & Daily requirements \\
\hline Energy (kcal) & * \\
\hline Carbohydrate (g) & ** \\
\hline Protein (g) & ** \\
\hline Fat (g) & ** \\
\hline \multirow{2}{*}{ Vitamin A ( $\mu \mathrm{g})$} & $750-1500 \mu g$ (0-13 age) \\
\hline & $3000 \mu g(>13$ age $)$ \\
\hline Vitamin D ( $\mu \mathrm{g})$ & $15 \mu \mathrm{g}$ \\
\hline Vitamin E (mg) & $4.0-10.7 \mu \mathrm{g}$ \\
\hline Vitamin C (mg) & $250-500 \mathrm{mg}$ \\
\hline \multirow{2}{*}{ Vitamin K ( $\mu \mathrm{g})$} & $2-60 \mu \mathrm{g}(0-13$ age $)$ \\
\hline & $75-120 \mu g$ (>13 age) \\
\hline Folic acid ( $\mu \mathrm{g})$ & $\begin{array}{c}1000 \mu \mathrm{g} \\
\text { (Three times a week) }\end{array}$ \\
\hline \multirow{2}{*}{ Iron (mg) } & $0.3-8 \mathrm{mg}(0-13 \mathrm{age})$ \\
\hline & 8-18 mg (>13 age) \\
\hline \multirow{2}{*}{ Copper (mg) } & $0.8-2.8 \mu \mathrm{g}(0-13$ age $)$ \\
\hline & $4 \mu g$ (>13 age) \\
\hline \multirow{2}{*}{ Zinc (mg) } & 2-8 mg (0-13 age) \\
\hline & $25-40 \mathrm{mg}$ (>13 age) \\
\hline
\end{tabular}

* Daily average energy intake was calculated using the Curreri formula, ${ }^{* *}$ Macronutrient requirements were evaluated on the basis of Clark et al. (15). Micronutrient requirements were evaluated on the basis of Chan et al. (6), and Rodriguez et al. (16). The percentages of children meeting the micronutrient requirements were calculated according to the sub-limits mentioned above.

\subsection{Statistical Analysis}

The Kolmogorov-Smirnov test was used to assess the normality of the distributions. Independent Sample T-Test was used to a statistical comparison between two independent groups, and the One-way Anova test for between more than two independent groups. Pearson Correlation test was used to evaluate the relationship between the mean age of children and the percentages of meeting energy and macronutrient requirements. Data were shown as the mean and standard deviation. The nominal variables were analyzed using the $\chi^{2}$ test. $P<0.05$ was considered significant. All statistical analyses were performed using the SPSS 22.0 (Statistical Package for Social Sciences) program. 


\section{RESULTS}

The participants included 19 (42.2\%) females and 26 (57.8\%) males with a mean age of $6.0 \pm 4.4$ years. Most of the children (55.5\%) were between 2 and 3 years old. The mean body weight reported at admission was $22.7 \pm 13.7 \mathrm{~kg}$. Four percent of the children fell below the $3^{\text {rd }}$ percentile, $85 \%$ were between the $3^{\text {rd }}$ and $97^{\text {th }}$ percentiles, and $11 \%$ were over the $97^{\text {th }}$ percentile according to weight for age standards at admission. The most common cause of burns was scalding in 34 (75.6\%) children, followed by flame burns in 10 (22.2\%) children and electrical burns in $1(2.2 \%)$ child. The mean \%TBSA was $14.5 \pm 7.4 \%$ (range of 5-34\%). Thirty-five (77.8\%) children had second-degree burns, seven (15.6\%) had thirddegree burns, and three (6.7\%) had first-degree burns. In 17 children (37.8\%), the burns covered less than $<10 \%$ of TBSA, in 21 children (46.6\%) the burns covered $10-20 \%$ of TBSA, whereas in 7 children (15.6\%), the burns covered $>20 \%$ of TBSA.

Particularly in 4-6 and 15-18 age groups, energy and macronutrient intakes were higher than other age groups. In line with energy and macronutrient intakes, except for vitamin $C$ and vitamin $D$, vitamin and mineral intakes were higher in 4-6 and 15-18 age groups (Table 2).

Table 2. Mean Daily Intakes for Energy and Nutrients According to Age Groups

\begin{tabular}{|c|c|c|c|c|c|}
\hline $\begin{array}{l}\text { Energy and } \\
\text { nutrients }\end{array}$ & $\begin{array}{l}2-3 \text { age } \\
(n=19)\end{array}$ & $\begin{array}{c}\text { 4-6 age } \\
(n=7)\end{array}$ & $\begin{array}{c}7-10 \text { age } \\
(n=12)\end{array}$ & $\begin{array}{c}11- \\
14 \text { age } \\
(n=4)\end{array}$ & $\begin{array}{c}15-18 \text { age } \\
(n=3)\end{array}$ \\
\hline Energy (kcal) & $\begin{array}{c}696.5 \pm \\
255.9\end{array}$ & $\begin{array}{c}1053.2 \pm \\
310.2\end{array}$ & $\begin{array}{c}768.4 \pm \\
336.3\end{array}$ & $\begin{array}{c}732.2 \pm \\
345.4\end{array}$ & $\begin{array}{c}1103.8 \pm \\
574.6\end{array}$ \\
\hline $\begin{array}{l}\text { Carbohydrate } \\
\text { (g) }\end{array}$ & $80.5 \pm 34.2$ & $\begin{array}{c}115.4 \pm \\
35.0\end{array}$ & $\begin{array}{c}82.3 \pm \\
32.2\end{array}$ & $\begin{array}{c}84.7 \pm \\
32.5\end{array}$ & $\begin{array}{c}144.2 \pm \\
87.23\end{array}$ \\
\hline Protein (g) & $23.4 \pm 9.2$ & $39.7 \pm 12.8$ & $\begin{array}{c}31.3 \pm \\
16.0\end{array}$ & $\begin{array}{c}25.4 \pm \\
13.4\end{array}$ & $\begin{array}{c}40.3 \pm \\
24.9\end{array}$ \\
\hline Fat (g) & $30.0 \pm 12.5$ & $46.7 \pm 14.4$ & $\begin{array}{c}33.5 \pm \\
17.3 \\
\end{array}$ & $\begin{array}{c}30.9 \pm \\
18.7 \\
\end{array}$ & $\begin{array}{c}38.4 \pm \\
20.6 \\
\end{array}$ \\
\hline $\begin{array}{l}\text { Vitamin A } \\
(\mu \mathrm{g})\end{array}$ & $\begin{array}{c}315.2 \pm \\
134.8\end{array}$ & $\begin{array}{c}495.8 \pm \\
199.6\end{array}$ & $\begin{array}{c}380.9 \pm \\
177.6\end{array}$ & $\begin{array}{c}449.8 \pm \\
330.1\end{array}$ & $\begin{array}{c}1557.0 \pm \\
1621\end{array}$ \\
\hline $\begin{array}{l}\text { Vitamin D } \\
(\mu \mathrm{g})\end{array}$ & $1.1 \pm 1.2$ & $0.9 \pm 0.6$ & $0.6 \pm 0.7$ & $\begin{array}{c}0.4 \pm \\
0.6\end{array}$ & $0.3 \pm 0.4$ \\
\hline $\begin{array}{l}\text { Vitamin E } \\
\text { (mg) }\end{array}$ & $3.4 \pm 2.1$ & $7.7 \pm 3.7$ & $5.3 \pm 3.1$ & $\begin{array}{c}5.3 \pm \\
2.9\end{array}$ & $8.2 \pm 7.9$ \\
\hline $\begin{array}{l}\text { Vitamin C } \\
\text { (mg) }\end{array}$ & $37.2 \pm 16.2$ & $51.1 \pm 25.5$ & $\begin{array}{c}57.2 \pm \\
28.1\end{array}$ & $\begin{array}{c}59.7 \pm \\
42.4\end{array}$ & $\begin{array}{c}144.8 \pm \\
160.1\end{array}$ \\
\hline $\begin{array}{l}\text { Vitamin K } \\
(\mu \mathrm{g})\end{array}$ & $\begin{array}{l}61.5 \pm \\
38.47\end{array}$ & $\begin{array}{c}119.6 \pm \\
34.9\end{array}$ & $\begin{array}{c}99.3 \pm \\
52.8\end{array}$ & $\begin{array}{c}99.2 \pm \\
47.3\end{array}$ & $\begin{array}{c}156.4 \pm \\
95.1\end{array}$ \\
\hline $\begin{array}{l}\text { Folic acid } \\
(\mu \mathrm{g})\end{array}$ & $64.7 \pm 32.1$ & $\begin{array}{c}120.7 \pm \\
18.8\end{array}$ & $\begin{array}{c}105.0 \pm \\
46.5\end{array}$ & $\begin{array}{c}102 . \pm \\
46.8\end{array}$ & $\begin{array}{c}229.9 \pm \\
165.8\end{array}$ \\
\hline Iron (mg) & $3.6 \pm 1.2$ & $5.4 \pm 1.4$ & $4.8 \pm 2.2$ & $\begin{array}{c}4.1 \pm \\
1.9\end{array}$ & $6.5 \pm 3.7$ \\
\hline Copper (mg) & $0.6 \pm 0.2$ & $1.1 \pm 0.3$ & $0.9 \pm 0.3$ & $\begin{array}{c}0.8 \pm \\
0.3\end{array}$ & $1.2 \pm 0.7$ \\
\hline Zinc (mg) & $3.4 \pm 1.5$ & $6.3 \pm 1.9$ & $4.8 \pm 2.4$ & $\begin{array}{c}4.0 \pm \\
2.3\end{array}$ & $7.0 \pm 4.4$ \\
\hline
\end{tabular}

The status of children's energy and nutrient intake to meet the requirements was shown in Table 3. None of the children reached the energy, carbohydrate, protein, folic acid, and vitamin D intake requirements.

There was no statistically difference between genders in terms of meeting energy and nutrient intakes $(P>0.05)$.

When the energy and macronutrient intakes of pediatric burned patients were evaluated, it was found that $67.7 \%$ of the children met $20-50 \%$ of energy, while $71.1 \%$ met $20-50 \%$ of both protein and carbohydrate. In addition, it was determined that $46.7 \%$ of the children meet the fat above $70 \%$.

Table 3. The meeting status of the requirements for energy and nutrients by age groups

\begin{tabular}{|c|c|c|c|c|c|c|}
\hline $\begin{array}{l}\text { Energy and } \\
\text { nutrients }\end{array}$ & $\begin{array}{l}2-3 \text { age } \\
(n=19)\end{array}$ & $\begin{array}{c}4-6 \text { age } \\
(n=7)\end{array}$ & $\begin{array}{c}7-10 \\
\text { age } \\
(n=12)\end{array}$ & $\begin{array}{c}11- \\
14 \text { age } \\
(n=4)\end{array}$ & $\begin{array}{c}15-18 \\
\text { age } \\
(n=3)\end{array}$ & $\begin{array}{c}\text { Total } \\
(n=45)\end{array}$ \\
\hline & $n-\%$ & $n-\%$ & $n-\%$ & $n-\%$ & $n-\%$ & $n(\%)$ \\
\hline Energy & $0(0.0)$ & $0(0.0)$ & $0(0.0)$ & $0(0.0)$ & $0(0.0)$ & $0(0.0)$ \\
\hline Carbohydrate & $0(0.0)$ & $0(0.0)$ & $0(0.0)$ & $0(0.0)$ & $0(0.0)$ & $0(0.0)$ \\
\hline Protein & $0(0.0)$ & $0(0.0)$ & $0(0.0)$ & $0(0.0)$ & $0(0.0)$ & $0(0.0)$ \\
\hline Fat & $7(36.8)$ & $\begin{array}{c}3 \\
(42.9)\end{array}$ & $\begin{array}{c}12 \\
(100.0)\end{array}$ & $4(100.0)$ & $\begin{array}{c}3 \\
(100.0)\end{array}$ & $\begin{array}{c}29 \\
(64.4)\end{array}$ \\
\hline Vitamin A & $0(0.0)$ & $\begin{array}{c}1 \\
(14.3)\end{array}$ & $0(0.0)$ & $1(25.0)$ & $\begin{array}{c}1 \\
(33.3)\end{array}$ & $3(6.6)$ \\
\hline Vitamin D & $0(0.0)$ & $0(0.0)$ & $0(0.0)$ & $0(0.0)$ & $0(0.0)$ & $0(0.0)$ \\
\hline Vitamin $\mathrm{E}$ & $7(36.8)$ & $\begin{array}{c}7 \\
(100.0)\end{array}$ & $8(66.7)$ & $3(75.0)$ & $\begin{array}{c}1 \\
(33.3)\end{array}$ & $\begin{array}{c}26 \\
(57.8)\end{array}$ \\
\hline Vitamin C & $0(0.0)$ & $0(0.0)$ & $0(0.0)$ & $0(0.0)$ & $\begin{array}{c}1 \\
(33.3)\end{array}$ & $1(2.2)$ \\
\hline Vitamin K & $\begin{array}{c}19 \\
(100.0)\end{array}$ & $\begin{array}{c}7 \\
(100.0)\end{array}$ & $\begin{array}{c}12 \\
(100.0)\end{array}$ & $4(100.0)$ & $\begin{array}{c}2 \\
(66.7)\end{array}$ & $\begin{array}{c}44 \\
(97.8)\end{array}$ \\
\hline Folic acid & $0(0.0)$ & $0(0.0)$ & $0(0.0)$ & $0(0.0)$ & $0(0.0)$ & $0(0.0)$ \\
\hline Iron & $\begin{array}{c}19 \\
(100.0)\end{array}$ & $\begin{array}{c}7 \\
(100.0)\end{array}$ & $\begin{array}{c}12 \\
(100.0)\end{array}$ & $4(100.0)$ & $\begin{array}{c}3 \\
(100.0)\end{array}$ & $\begin{array}{c}45 \\
(100.0)\end{array}$ \\
\hline Copper & $3(15.8)$ & $\begin{array}{c}6 \\
(85.7)\end{array}$ & $7(58.3)$ & $1(25.0)$ & $0(0.0)$ & $\begin{array}{c}17 \\
(37.7)\end{array}$ \\
\hline Zinc & $\begin{array}{c}15 \\
(78.9) \\
\end{array}$ & $\begin{array}{c}7 \\
(100.0) \\
\end{array}$ & $\begin{array}{c}10 \\
(83.3) \\
\end{array}$ & $3(75.0)$ & $0(0.0)$ & $\begin{array}{c}35 \\
(77.7) \\
\end{array}$ \\
\hline
\end{tabular}

The percentages of meeting the energy and nutrient requirements decreased by age $(P<0.05)$. A modest but statistically significant negative correlation was found between the mean age of the children and the percentages of meeting energy requirement $(P=0.002, r=-0.443)$ and fat requirements $(P=0.002, r=-0.459)$, whereas a weak but statistically significant negative correlation was found for carbohydrate $(P=0.009, \mathrm{r}=-0.383)$ and protein requirements $(P=0.032, r=-0.321)$.

The cause, degree, and burn percentages were not significantly associated with meeting daily energy and nutrient requirements $(P>0.05)$. Burn areas such as the head, neck, and arm also did not influence the percentage 
of children meeting energy and macronutrient requirements $(P>0.05)$.

In this study, 8 (17.8\%) children received oral enteral nutrition supplements. Oral enteral nutrition was shown to contribute to $26.3 \%$ of the daily energy intake in these children. When daily intakes were compared with who did not receive oral enteral nutrition $(n=37)$, the percentages of children who met energy, carbohydrate, and fat requirements were significantly higher in children who received oral enteral nutrition $(P<0.05)$. However, these results did not hold for protein and micronutrients $(P>0.05)$.

The mean energy and nutrient intakes on days with and without a perioperative fasting period was shown in Table 4. The percentage of children who met protein requirements was significantly lower on the days with perioperative fasting periods $(P<0.05)$, whereas this difference was found not statistically significant for energy, carbohydrates and fat $(P>0.05)$. For micronutrient intakes, only the percentages of children meeting the vitamin E, folic acid, copper, and zinc requirements were significantly lower on days with perioperative fasting periods $(P<0.05)$.

Table 4. Comparison of energy and nutrients intakes according to perioperative fasting period

\begin{tabular}{|c|c|c|c|}
\hline Energy and nutrients & $\begin{array}{l}\text { Days with a } \\
\text { perioperative } \\
\text { fasting period }\end{array}$ & $\begin{array}{l}\text { Days without a } \\
\text { perioperative } \\
\text { fasting period }\end{array}$ & $p$ \\
\hline Energy (kcal) & $661.5 \pm 350.5$ & $904.3 \pm 440.0$ & 0.068 \\
\hline Carbohydrate (g) & $81.2 \pm 47.4$ & $97.3 \pm 54.0$ & 0.769 \\
\hline Protein (g) & $23.4 \pm 14.8$ & $34.8 \pm 20.5$ & $0.045^{*}$ \\
\hline Fat (g) & $29.9 \pm 19.5$ & $38.1 \pm 21.7$ & 0.453 \\
\hline Vitamin A ( $\mu \mathrm{g})$ & $360.8 \pm 319.3$ & $495.6 \pm 313.2$ & 0.312 \\
\hline Vitamin D ( $\mu \mathrm{g})$ & $0.7 \pm 1.2$ & $1.1 \pm 1.3$ & 0.061 \\
\hline Vitamin E (mg) & $4.2 \pm 3.4$ & $6.1 \pm 5.3$ & $0.034^{*}$ \\
\hline Vitamin C (mg) & $45.2 \pm 29.3$ & $55.3 \pm 40.1$ & 0.786 \\
\hline Vitamin K ( $\mu \mathrm{g})$ & $75.0 \pm 56.3$ & $111.3 \pm 91.1$ & 0.082 \\
\hline Folic acid ( $\mu \mathrm{g})$ & $70.3 \pm 40.3$ & $115.6 \pm 77.6$ & $0.048^{*}$ \\
\hline Iron (mg) & $3.7 \pm 1.9$ & $5.1 \pm 3.3$ & 0.176 \\
\hline Copper (mg) & $0.7 \pm 0.4$ & $0.9 \pm 0.5$ & $0.004^{*}$ \\
\hline Zinc (mg) & $3.8 \pm 2.5$ & $5.2 \pm 3.4$ & $0.020^{*}$ \\
\hline
\end{tabular}

${ }^{*} P<0.05$

\section{DISCUSSION}

Several researchers have investigated the nutritional requirements in children with thermal injuries. It is well documented that the maintenance of adequate nutrition is vital in pediatric burned patients because they have inadequate energy reserves and greater energy and nutrient requirements than adults. However, no children reached the energy, carbohydrate, and protein intake requirements; these results were not valid for fat intake. These findings may be a result of children and their caregivers choosing fast food, snacks, etc., instead of hospital and home foods and focusing on food consumption rather than adequate and balanced nutrition. These results indicate that children and their caregivers must receive nutritional education because the diets of pediatric burned patients are substantially inadequate. It has been observed that most children can meet only their daily vitamin $E$, vitamin $\mathrm{K}$, zinc, and iron requirements. The results in regard to vitamin and mineral requirements in pediatric burned patients remain controversial. Before considering a vitamin and mineral supplement, the nutritional status of the child and bioavailability of a nutritional intervention should be determined (18).

Acute nutritional losses occur because of burn-related catabolism, which makes it very difficult to meet requirements in a short period (19). Enteral nutrition is the preferred option to reach adequate nutrition, prevent metabolic complications in pediatric burned patients who require more nutritional intake because it decreases the risk of infectious complications (20-22). Shahi et. al. recommend early initiation of oral feeding within four hours of presentation in neurologically appropriate pediatric burned patients (23). Oral route with high protein foods and small, frequent feedings is always preferred, if the patient is able to consume adequate according to guidelines. For instance, when the patient is unable to eat or consume adequate intake (defined as at least $60 \%$ of energy requirement), enteral and/ or parenteral nutrition should be considered (24). In our study, it was found that enteral nutrition helps to meet the increased energy and macronutrient needs. In addition, it was found that $82.2 \%$ of the children had an energy intake percentage below $50 \%$. Despite all these reasons, patients were not given a standard enteral nutritional support in the burn centre.

Dylewski et al. noted that the average age of malnourished burned children was older than that of well-nourished burned children (25). Similarly in this study, the percentages who met daily energy and nutrient requirements decreased with age. This may have been due to increased needs and the food that older children prefer.

There are several factors that affect food consumption, such as perioperative fasting periods. These factors trigger nutritional depletion (20). Therefore, nutritional support is absolutely necessary to regulate preoperative nutritional deficiency and to modulate the transition from catabolism to anabolism during the postoperative period (26). Allowing the intake of clear fluids before anesthesia improves child and parental satisfaction, increases gastric $\mathrm{pH}$, increases the ingestion of calories, decreases the risk of hypoglycemia and lipolysis, and improves fluid homeostasis. The European Society of Anesthesiology has reported that children should 
be encouraged to drink clear fluids up to $2 \mathrm{~h}$ before elective surgery $(27,28)$. The American Society of Anesthesiologists (ASA) recommends restriction of clear fluids for two hours, breast milk for four hours, infant formula for six hours, a light meal or non-human milk for six hours and a large fatty meal for eight hours $(17,29)$. However, currently, most burn treatment centers maintain patients under the protocol NPO, or nothing through the mouth, for at least $8 \mathrm{~h}$ or overnight fasting before any surgical procedure (30).

The study was conducted on the declared weight of the children, and it is a limitation that their weight tracking was not assessed. In previous studies, only protein and energy intake were considered when the nutritional status of pediatric burned patients is determined. In our study, the energy, micronutrient and macronutrient intake of children were assessed.

In conclusion, it is difficult for pediatric burned patients to meet nutritional requirements. To provide adequate and balanced nutrition, a dietitian should determine a nutrition plan for each child based on individual factors. Pediatric burned patients should be closely monitored for deterioration in nutritional status because burns are dynamic. In addition, enteral nutritional support should be initiated to optimize burn care. Nutrition education for caregivers who assist in feeding and pediatric burned patients should be a part of the burn unit routine.

It will be needed to create a specific, flexible feeding schedule in the multidisciplinary approach. It should be both practical, suitable for the hospital environment and provide the nutritional needs of the burn patient.

\section{REFERENCES}

[1] Diler B, Dalgic N, Karadag CA, Dokucu Ai. Epidemiology and infections in a pediatric burn unit: experience of three years. J Pediatr Inf. 2012 ;6: 40-45.

[2] Zor Fatih, Ersoz N, Kulahci Y, Kapı E, Bozkurt M. Gold Standards in Primary Care Burn Treatment. Dicle Med J. 2009; 36: 219- 225.

[3] Sarı O, Onar T, Aydogan U. Wound and burn management in primary care. Smyrna Med J. 2011; 1: 53-56.

[4] O'Keefe GE, Hunt JL, Purdue GF. An evaluation of risk factors for mortality after burn trauma and the identification of genderdependent differences in outcomes. Journal of the American college of surgeons. 2001; 192: 153-160.

[5] Deveci M, Sengezer M, Er E, Selmanpakoglu N. Mortality analysis in burns. Turk J Plast Surg. 1998; 6: 108-113.

[6] Chan MM, Chan GM. Nutritional therapy for burns in children and adults. Nutrition. 2009; 25: 261-269.

[7] Cronin KJ, Butler PEM, McHugh M, Edwards G. A 1-year prospective study of burns in an Irish paediatric burn unit. Burns. 1996; 22: 221224.

[8] Paulman AA, Harrison JD. Taylor's family medicine handbook. In: Basak O, Demirag SA eds. 3rd ed. Ankara, Gunes Med Press. 2011: 739-745.
[9] Guzel A, Aksu B, Aylanç H, Duran R, Karasalihoğlu S. Scalds in pediatric emergency department: a 5-year experience. Journal of burn care \& research. 2009;30(3), 450-456.

[10] Sunderman C, Gottschlich M, Allgeier C, James L, Boerger L, Warner P. 55 Utilization of Z-Scores to Identify Malnutrition in the Pediatric Burn Abuse and Neglect Population. Journal of Burn Care \& Research. 2018; 39(suppl_1), 32.

[11] Aktac S, Basoglu IA, Oguz E. Nutritional therapy in pediatric burn patients. In: Tayfur M (ed). Nutrition and Dietetics Current Issues 7. Ankara: Hatiboğlu Publisher; 2018.p. 67- 85.

[12] Dibley MJ, Goldsby JB, Staehling NW, Trowbridge FL. Development of normalized curves for the international growth reference: historical and technical considerations. Am J Clin Nutr. 1987; 46: 736-748.

[13] Behrman R.E. Nelson Textbook of Pediatrics (14th ed) Philadelphia: WB Saunders, 1992.

[14] Murray KA. Burn Basics: How to Assess and Treat. The Canadian Journal of CME. 2007; 19: 62-64.

[15] Clark A, Imran J, Madni T, Wolf SE. Nutrition and metabolism in burn children. Burns Trauma. 2017; 5:11.

[16] Rodriguez NA, Jeschke MG, Williams FN, Kamolz FN, Herndon DV. Nutrition in burns: Galveston contributions. J Parenter Enteral Nutr. 2011; 35: 704-714.

[17] The American Society of Anesthesiologists, Inc. Lippincott Williams \& Wilkins. Anesthesiology 2011; 114: 495-511.

[18] McCarthy H. Burns. In: Shaw V (ed). Clinical Paediatric Dietetics (4th ed) UK: John Wiley \& Sons; 2015: 707-14.

[19] Vijfhuize S, Verburg M, Marino L, van Dijk M, Rode H. An evaluation of nutritional practice in a paediatric burns unit. S Afr Med J. 2010; 100: 383-386.

[20] Gottschlich MM, Jenkins ME, Mayes T, Khoury J, Kagan RJ, Warden GD. An evaluation of the safety of early vs delayed enteral support and effects on clinical, nutritional, and endocrine outcomes after severe burns. J Burn Care Rehabil. 2002; 23: 401-15.

[21] Lu G, Huang J, Yu J, Zhu Y, Cai L, Gu Z, et al. Influence of early post-burn enteral nutrition on clinical outcomes of patients with extensive burns. J Clin Biochem Nutr. 2011;48(3):222- 225.

[22] Mehta NM, Skillman HE, Irving SY, Coss-Bu JA, Vermilyea S, Farrington EA, et al. Guidelines for the provision and assessment of nutrition support therapy in the pediatric critically ill patient: Society of Critical Care Medicine and American Society for Parenteral and Enteral Nutrition. JPEN J Perenter Enteral Nutr. 2017;41(5):706742.

[23] Shahi, Niti, et al. Why delay? Early Enteral Nutrition in Pediatric Burn Patients Improves Outcomes. Journal of Burn Care \& Research, 2020.

[24] Rollins C, Huettner F, Neumeister MW. Clinician's Guide to Nutritional Therapy Following Major Burn Injury. Clin Plast Surg. 2017;44(3):555-566.

[25] Dylewski ML, Prelack K, Weber JM, et al. Malnutrition among pediatric burn patients: A consequence of delayed admissions. Burns. 2010;36(8):1185-1189.

[26] Kilicturgay AS, Sarkut P. Perioperative Nutritional Support in Surgical Patient. Turkiye Klinikleri J Gen Surg-Special Topics. 2015; 8: 44-50.

[27] Splinter WM, Schreiner MS. Preoperative fasting in children. Anesthesia \& Analgesia. 1999; 89: 80-89.

[28] Smith I, Kranke P, Murat I, Smith A, O'Sullivan G, Søreide E, et al. Perioperative fasting in adults and children: guidelines from the European Society of Anaesthesiology. Eur J Anaesthesiology. 2011; 28: 556-569. 
[29] The American Society of Anesthesiologists, Inc. Wolters Kluwer Health, Inc. All Rights Reserved. Anesthesiology 2017; 126:376-93
[30] Togo HYA, Lopes EC. Preoperative fasting reduction in burned patients: A systematic review, Burns Open. 2020;4(4):176- 182.

How to cite this article: Aktac S, Basoglu IA, Cebeci A, Oguz E, Gulada Omeroglu B. Determination of Energy and Nutrient Intakes in Pediatric Burned Patients. Clin Exp Health Sci 2021; 11: 689-694. DOI: 10.33808/clinexphealthsci.750048 